MINERALOGIA, 48, No 1-4: 167-179 (2017)

DE DE GRUYTER OPEN

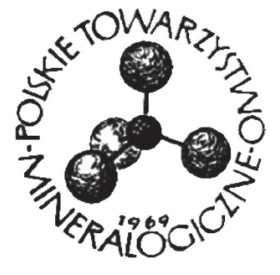

Original paper

\title{
The characteristics and the concept of the utilisation of post-production calcareous waste deposited in landfills
}

\author{
Anna Pajdak $^{1 *}$, Arkadiusz Szymanek ${ }^{2}$ \\ ${ }^{1}$ The Strata Mechanics Research Institute of the Polish Academy of Sciences, Reymonta 27, 30-059 Cracow, \\ Poland \\ ${ }^{2}$ Institute of Thermal Machinery, Czestochowa University of Technology, Armii Krajowej 21, 42-201 \\ Czestochowa, Poland \\ * Corresponding author \\ e-mail:pajdak@img-pan.krakow.pl
}

Received: April 24, 2017

Received in revised form: September 06, 2017

Accepted: September 06, 2017

Available online: September 30, 2017

\begin{abstract}
This article presents the results of research into calcareous waste from the production process of oxide propylene. The obtained results show a considerable chemical diversity of calcareous waste with a predominant percentage share of $\mathrm{Ca}, \mathrm{C}$ and $\mathrm{Cl}$, which are the products of the process. It was shown that the share of calcium bonded in $\mathrm{CaCO}_{3}$ was over $20 \%$, which is indicative of the secondary carbonisation process taking place in the waste. The morphological and structural analyses revealed that the grains had a surface area above $12 \%$ and a percentage porosity in the range of $25-35 \%$. The reactivity test made it possible to classify calcareous waste as a material for sorbents of 'satisfactory' sorption properties, insufficient to be effectively used in the power sector. For the stored waste to be reused, it is necessary to improve its sorption abilities through the application of a properly selected activation method.
\end{abstract}

Key-words: calcareous waste structure, reactivity of calcareous waste, reactivity test

\section{Introduction}

Calcareous waste constitutes a significant group of waste compounds disposed in landfills. The Polish economy generates approximately 1.5 million tons of highly calcareous waste, which derives mostly from the petrochemical, pharmaceutical, cosmetic, plastics, rubber, paint and varnish, and auxiliary agent industries. The most common 
calcareous waste that is generated by the aforementioned branches of industry includes carbide residue, carbonate deposits from decarbonising processes, and brine purification deposit, as well as waste from saponification and the production of polyol and polyurethane. The production and common use of polyols and polyurethanes, from the automotive and clothing industries to office equipment production, often involves the generation of hazardous waste. Such waste products are normally disposed of on hazardous waste sites, as there is no possibility to utilise them. However, owing to the fact that they provide a source of calcium compounds potentially usable in various branches of industry, there is a lot of research into their utilisation (Szymanek 2008; IUNG 2013). One of the industry branches that consumes considerable amounts of mining calcium compounds is the power industry. Through the combustion of fuels, it generates large amounts of gas pollutants, whose neutralisation usually involves calcium compounds (Markiewicz et al. 2013; Markiewicz et al. 2014). Thus, the power industry is a potential purchaser of calcareous waste which, if properly processed, can be used as a material for sorbents of acidic gaseous pollutants.

\section{The origin of waste generation}

A method of propylene oxide production most commonly used in industry is the chlorine method. The basic raw material used for this production is propylene which, by reaction with hypochlorous acid, forms propylene chlorohydrin. In the technological process calcium hydroxide is used for the saponification of the chlorohydrin. At the end of the installation, as shown in Figure 1, the calcium hydroxide of an initial concentration of $14-18 \%$ is used in the saponifier and next, after changing the $\mathrm{pH}$ reaction of the chlorohydrin to strongly basic, it is removed to a waste disposal site.

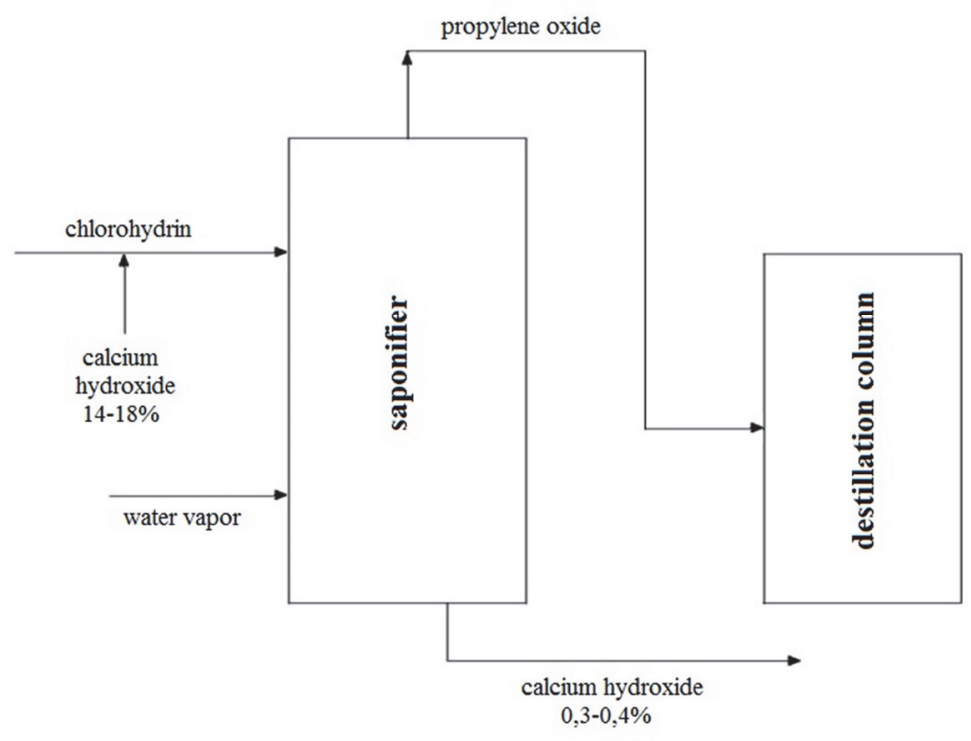

Fig. 1. Diagram of the final propylene oxide production system. 
After the saponification process, the calcium hydroxide is chemically inactive. For the waste to be reused, its chemical activity must be restored. An attempt was made in this study to identify the physiochemical properties of the stored waste. It was assumed that the migration of some chemical compounds might occur during the storage of waste on a waste disposal ground due to variable weather conditions and storage time, as well as the specific characteristics of the deposited compounds and mixing caused by new waste batches disposed of on the waste disposal ground. Its reactivity in relation to acid pollutants was also specified according to the scale applied by Ahlstrom's Pyropower (Ahlstrom 1995; Szymanek 2000; Szymanek 2008; Walawska et al. 2012; Kochel et al. 2015; www.czatkowice.pl 2015; Hycnar et al. 2016).

\section{Research material}

Samples of limestone waste were used as the research material. They were extracted from a landfill that was divided into square-shaped sectors. The distance between the sectors and between the sectors and the edge of the landfill was approximately $15 \mathrm{~m}$. Two samples were taken from each spot, one from the surface layer and one from the depth of 0.5-1 m. This article presents the analyses of 4 samples of calcareous waste. The latter were extracted by the use of probes constructed especially for that purpose. They were made of $100 \mathrm{~mm}$ diameter PVC tubes, which were driven into the deposit to a depth of $2 \mathrm{~m}$. At the end of each tube a shut-off valve was installed to prevent the material from sliding out. The scheme of the sampling probe is shown in Figure 2.
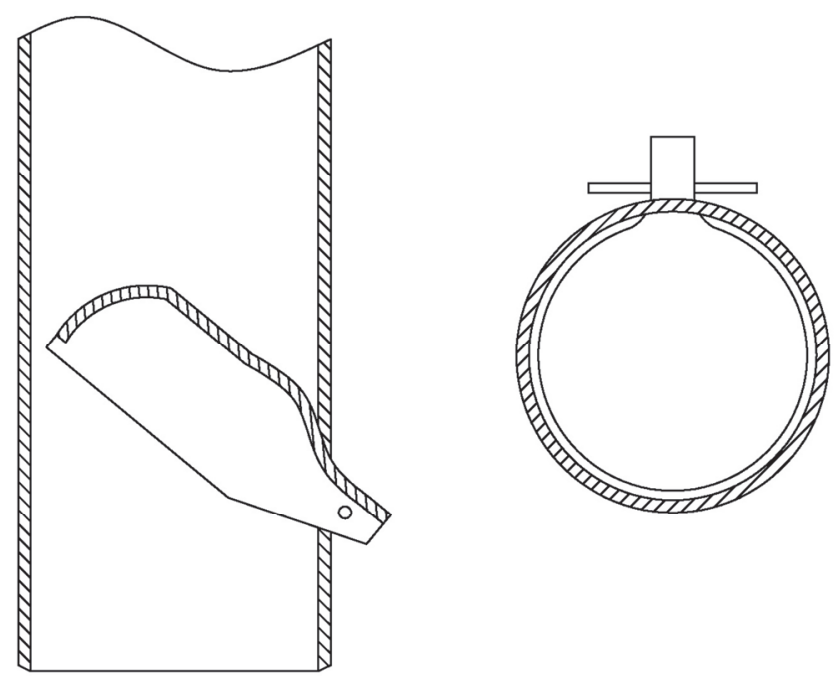

Fig. 2. Sampling probe with a closing valve.

The samples of the calcareous waste from propylene oxide production had the form of partially lumped material with slimy consistency and an odour characteristic of polyols. The moisture content ranged from $5-90 \%$ depending on the location, the depth of the 
sample extraction spot and the weather conditions. The examined material was subjected to drying and homogenisation, as well as laboratory and test measurements.

\section{Research methodology}

The research focus comprised the morphological, chemical and structural characteristics of the calcareous waste deposited on waste disposal grounds, as well as their reactivity.

The material was subjected to grain size analysis using a laser diffraction particle size analyser LS 13320. A scanning electron microscope LEO 1430VP (SEM-EDS) was used to analyse the surface morphology of the samples and their elementary composition. The microscope consisted of an energy dispersive X-ray spectrometer with a secondary electrons detector and a backscattered electron detector. Backscattered electrons have high energy and made it possible to observe the topography of the sample surface. The microscope was equipped with an EDX Quantax 200 X-ray spectrometer with a XFlash 4010 detector, which was used to identify the chemical elements of the waste. The images were registered at magnifications of 100-2000x and EDS analyses were performed in selected areas of the samples. The qualitative and quantitative analyses of the elementary composition of the samples for a broad range of chemical elements were carried out using the WD-XRF method, which relies on measuring the secondary radiation of elements obtained as a result of their induction by X-ray radiation. The analysis was made using a WD-XRF "Spektroscan V" spectrometer equipped with a ${ }^{46} \mathrm{Pd}$ anode X-ray tube. The analysis of the composition and the spatial structure of the waste was carried out by the Xray powder diffraction technique using an X'Pert PRO Systems X-ray diffractometer. This method relies on registering images created as a result of the interaction of that radiation with the atomic electron clouds.

The structural parameters were determined by mercury porosimetry on an AutoPore 9500 analyser. The measurement involved intruding mercury into the pores of the material grains in the pressure range from $10^{-5}$ to $414 \mathrm{MPa}$. The percentage porosity and the surface area, as well as the total pore volume and mean pore size, were identified based on the Washburn equation (Washburn 1921).

Following the characteristics of the samples, their reactivity was analysed using the Ahlstrom Pyropower Development Laboratory test (Ahlstrom 1995). The aim of the analysis was to determine the reactivity index Ri of the calcareous waste. They were carried out on a laboratory test stand shown in Figure 3.

The main element of the test stand was an electric furnace, in which a quartz column was placed. A model gas containing sulphur dioxide, oxygen, nitrogen and carbon dioxide was introduced into the column. A sample of $1.5 \mathrm{~g}$ was placed in the reaction chamber and subjected to the model gas exposure for $1.5 \mathrm{~h}$. The temperature in the reaction chamber was maintained at a constant level of $378 \mathrm{~K}$ for the drying stage and $1123 \mathrm{~K}$ for the calcination and sorption properties tests.

The reactivity index was determined based on the elemental sulphur content in the samples before and after the sulphation process. The sulphur and carbon content measurement was performed on an elemental analyser LECO SC-144DR, which relies on the absorption of infrared radiation and is designed to measure the content of carbon and sulphur simultaneously (including sulphur ash) in a wide range of organic materials. The 
determination of carbon and sulphur consists of burning a sample placed in a ceramic crucible in a stream of pure oxygen and measuring the coefficient of infrared radiation absorption by $\mathrm{SO}_{2}$ and $\mathrm{CO}_{2}$, which is then converted into the percentage content of carbon and sulphur.

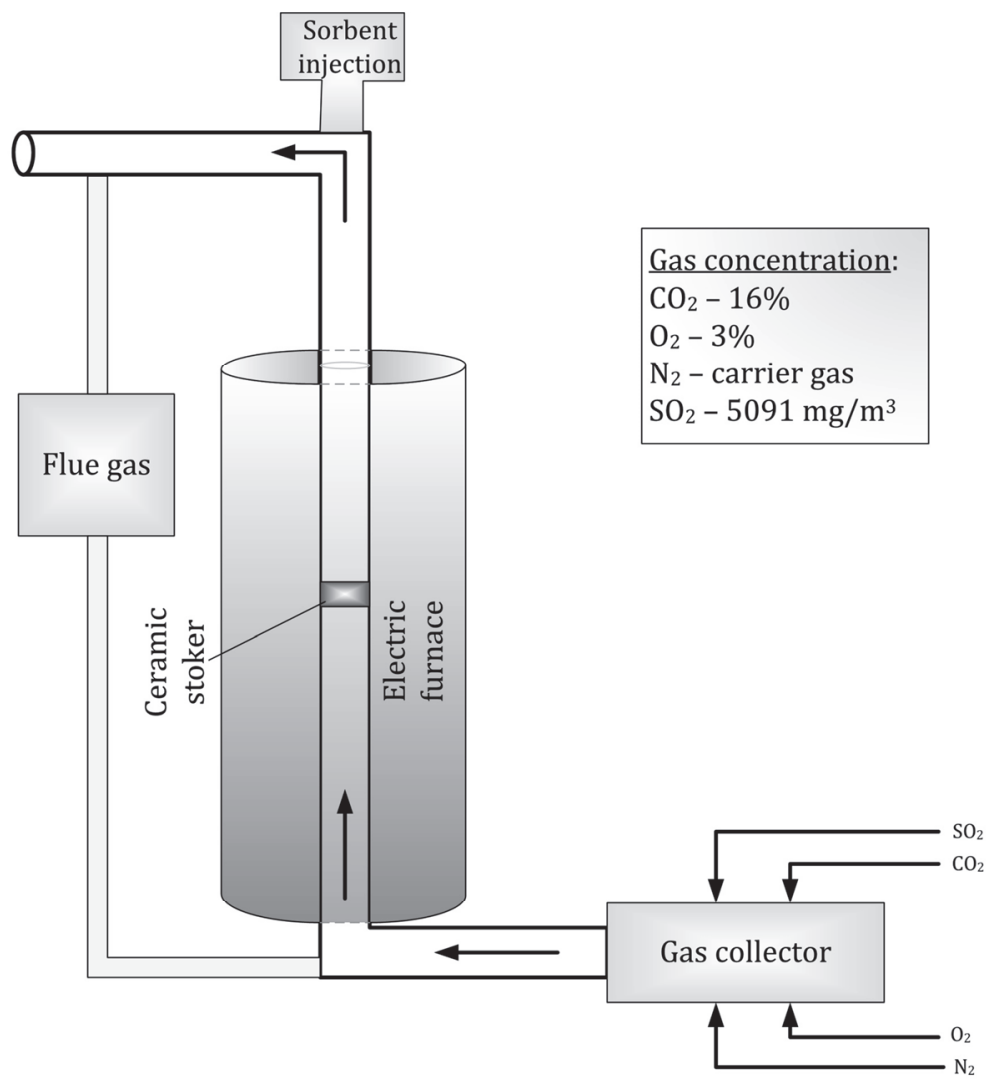

Fig. 3. The laboratory test stand.

The reactivity index was determined based on the Ahlstrom's test specifying the reactivity index $\mathrm{Ri}$, according to equation 1 . The reactivity scale shown in Table 1 was applied to estimate the sorption properties.

$$
R_{i}=\frac{\frac{x_{C a}}{100} \cdot \frac{M_{S}}{M_{C a}} \cdot\left(1-\frac{M_{C O_{2}}}{M_{C}} \cdot \frac{x_{C_{p}}}{100}-\frac{M_{S O_{2}}}{M_{S}} \cdot \frac{x_{S_{p}}}{100}\right)}{\frac{x_{S_{p}}-x_{S_{b}}}{100}+\frac{M_{C O_{2}}}{M_{C}} \cdot\left(\frac{x_{C_{p}} \cdot x_{S_{b}}-x_{C_{b}} \cdot x_{S_{p}}}{10000}\right)},
$$

where:

$R_{i}$ - reactivity index (-); 
$x_{C a}, x_{C_{p}}, x_{S_{p}}, x_{C_{b}}, x_{S_{b}}$ - percentage share of calcium in the sample, carbon in the sample after the sulphurisation process, sulphur after the sulphurisation process, carbon before the sulphurisation process, and sulphur before the sulphurisation process, respectively (\%); $M_{S}, M_{C a}, M_{C}, M_{C_{2}}, M_{S_{2}}$ - molar mass of sulphur, calcium, carbon, carbon dioxide, and sulphur dioxide, respectively $\left(\mathrm{kg} \mathrm{kmol}^{-1}\right)$.

TABLE 1

Scale of the reactivity (Ahlstrom 1995).

\begin{tabular}{ll}
\hline Sorbent assessment & $\mathrm{R}_{\mathrm{i}}$ \\
\hline Excellent & $<2.5$ \\
Very good & $2.5-3.0$ \\
Good & $3.0-4.0$ \\
Satisfactory & $4.0-5.0$ \\
Poor & $>5.0$ \\
\hline
\end{tabular}

\section{Research results}

\subsection{Physiochemical characteristics}

Calcareous waste samples extracted from areas A and B of the waste disposal ground, from the surface layer $(0 \mathrm{~m})$ and the depth of $0.5-1 \mathrm{~m}$ were subjected to SEM analysis. Figure 4 shows BSE microscans of the waste grain surface.

The analysed samples were morphologically different. The shape of the grains was slightly irregular of the average sphericity (Rawle 2000) with visible roughness of the surface. Single grains as well as agglomerates were observed. The average grain size $d_{3,2}$ (Sauter Mean Diameter) was in the range of 11.0-12.5 $\mu \mathrm{m}$. The EDS analyses made it possible to determine the percentage mass content of selected elements, which is shown in Table 2.

Calcium (Ca) had a significant mass percentage share in the analysed waste. Its source was the calcium hydroxide provided directly to the saponifier in the technological process of the propylene oxide production. The content of the calcium in the surface layers of the waste was $34.4-36.7 \%$. However, in the samples extracted from the depth of $0.5-1 \mathrm{~m}$, its content was a few per cent lower and amounted to $31.5-33.2 \%$. Considerable mass share of carbon was also recorded in the analysed waste. It is the product of the reaction of calcium bicarbonate with $\mathrm{CO}_{2}$ contained in the atmosphere. As the research data shows, the carbon (C) was the product of the secondary carbonisation process, which resulted from the reaction of $\mathrm{Ca}(\mathrm{OH})_{2}$ with $\mathrm{CO}_{2}$. The process took place not only on the surface on the deposit, which has direct contact with the air, but also in its upper layers. The percentage share of carbon in all of the analysed samples was in the range of 9.1-14.4\%. The presence of chlorine $(\mathrm{Cl})(3.2-6.1 \%)$ resulted from the fact that chlorohydrin was used in the reactor during the saponification process. Due to its tendency to be easily washed out, chlorine can 
migrate into the deposit and thus, as the depth increases, so does its content. In this research, a clear tendency confirming that phenomenon was not observed.
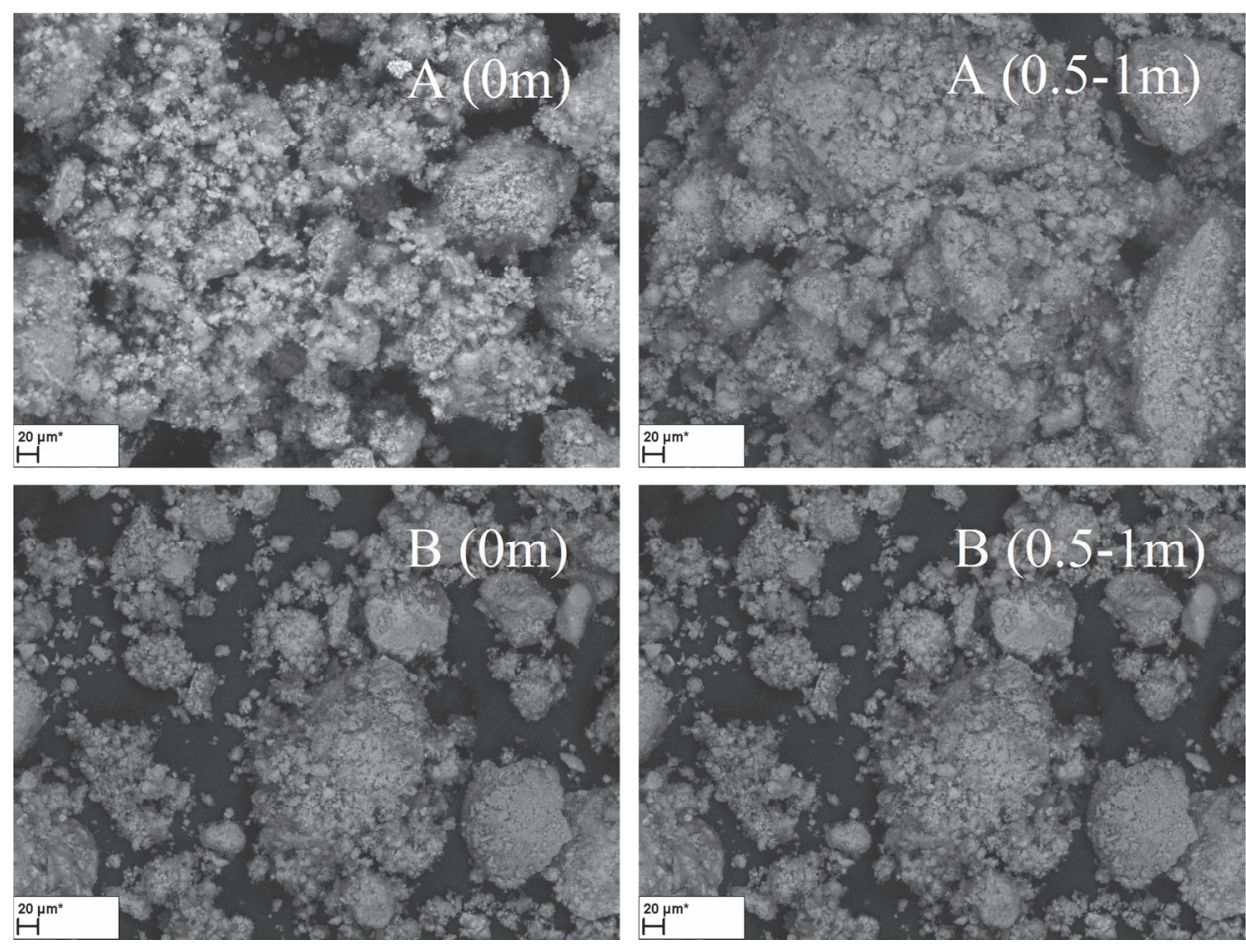

Fig. 4. Image of the morphology of the surface of the calcareous waste samples, BSE, mag. 500x.

TABLE 2

The percentage mass share of selected elements.

\begin{tabular}{|c|c|c|c|c|c|c|c|c|c|c|c|}
\hline \multirow{2}{*}{\multicolumn{2}{|c|}{$\begin{array}{l}\text { Area number and } \\
\text { extraction depth } \\
{[\mathrm{m}]}\end{array}$}} & \multicolumn{10}{|c|}{ The percentage mass share of elements $[\%]$} \\
\hline & & $\mathrm{Ca}$ & $\mathrm{C}$ & $\mathrm{Cl}$ & $\mathrm{Mg}$ & $\mathrm{Al}$ & $\mathrm{Si}$ & $\mathrm{O}$ & $\mathrm{Fe}$ & $\mathrm{S}$ & $\mathrm{Cu}$ \\
\hline \multirow{2}{*}{ A } & 0 & 34.4 & 9.1 & 3.2 & 2.5 & 0.6 & 0.8 & 46.9 & 2.5 & - & - \\
\hline & $0.5-1$ & 33.2 & 11.5 & 4.3 & 1.1 & 1.0 & 0.4 & 39.1 & 9.2 & 0.01 & 0.2 \\
\hline \multirow{2}{*}{ B } & 0 & 36.7 & 11.7 & 6.1 & 0.3 & 0.8 & 0.2 & 43.8 & 0.4 & - & - \\
\hline & $0.5-1$ & 31.5 & 14.4 & 4.6 & 1.0 & 0.6 & 0.8 & 45.8 & 1.3 & - & - \\
\hline
\end{tabular}

Apart from the elements which are products of the process of the technological production of propylene oxide, the EDS analyses also revealed the presence of magnesium, aluminium and silicon in amounts below 2.5\%, iron (0.4-9.2\%), as well as trace amounts of sulphur and copper in one of the samples (A, 0.5-1 m).

For further identification of the calcareous waste, the samples were subjected to WDXRF analysis. Figures 5-8 show the spectra of the calcareous waste samples. The analysis 
involved a monocrystal carbon and the exposure time was $5 \mathrm{sec}$. The peaks of calcium radiation are highlighted red.

The quantitative analysis showed that the biggest values were noted for calcium. They were in the range of $41-42 \%$, regardless of the area and the depth of the sample extraction. The samples from area A had a higher magnesium content - 2.6\% $(0 \mathrm{~m})$ and $4.7 \%(0.5$ $1 \mathrm{~m}$ ), respectively. The content of aluminium in the upper layers was approximately $1.5 \%$, much higher than in that from the depth of 0.5-1 m. Trace amounts not only of aluminium, but also magnesium and iron, occur in the calcium carbonate, which was the source of the calcium hydroxide used in the technological process. The presence of iron may also have been caused by the hydraulic transportation of the waste to the waste disposal ground. Apart from the alkaline elements and $\mathrm{Fe}, \mathrm{Si}, \mathrm{Ti}, \mathrm{Mn}, \mathrm{P}, \mathrm{S}, \mathrm{Cr}$, the content of heavy metals such as $\mathrm{Cu}, \mathrm{Ni}, \mathrm{Pb}, \mathrm{Zn}, \mathrm{Cd}$, as well as As and $\mathrm{Co}$ is worth noticing. The majority of these elements occurred in amounts not exceeding several dozens of $\mathrm{mg} \mathrm{kg}^{-1}$. The largest amount was found in the case of zinc (227-230 $\left.\mathrm{mg} \mathrm{kg}^{-1}\right)$.

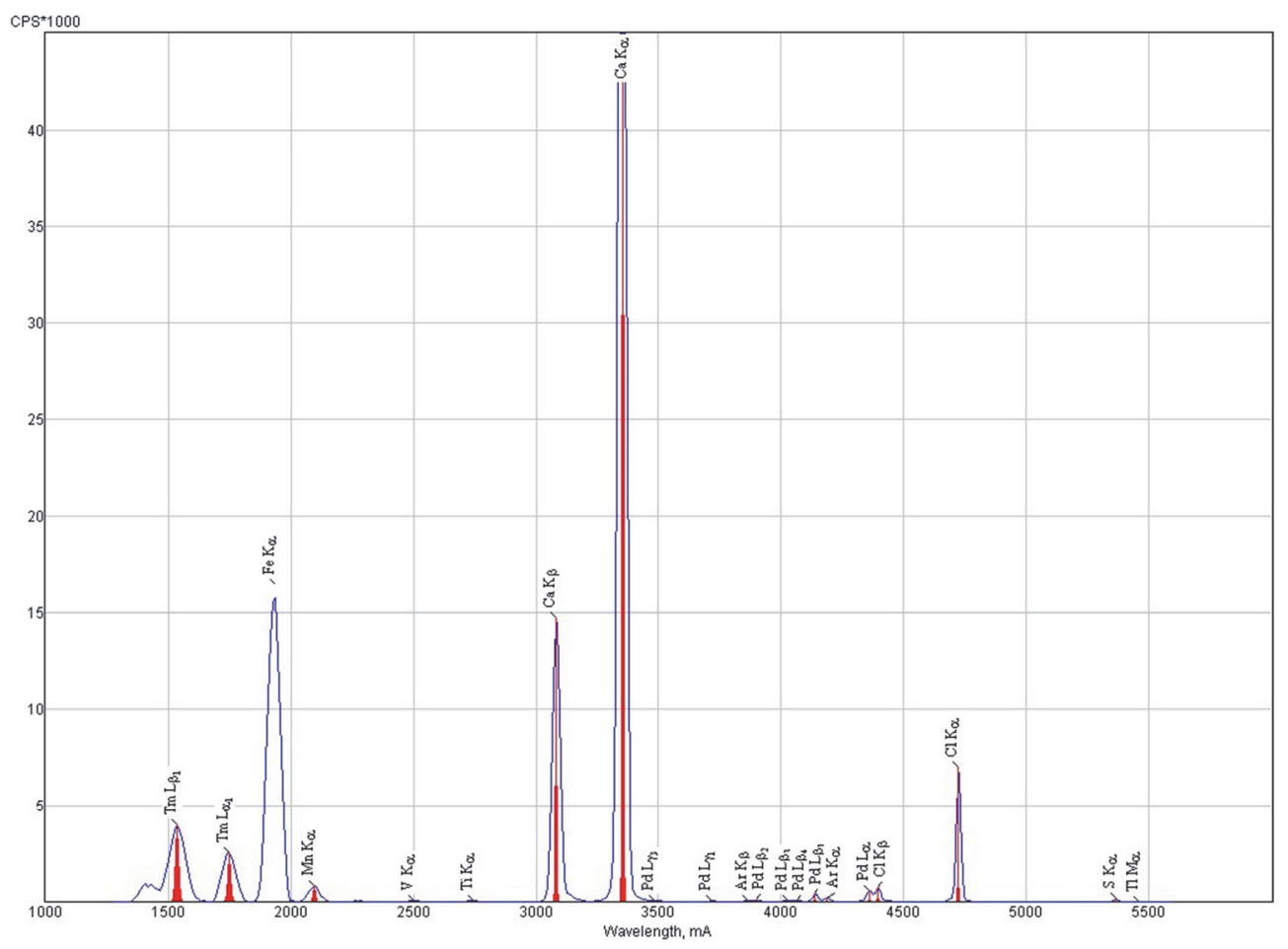

Fig. 5. XRF spectrum of calcareous waste sample A, $0 \mathrm{~m}$, crystal C (002), $40 \mathrm{kV}, 2.00 \mathrm{~mA}$. 


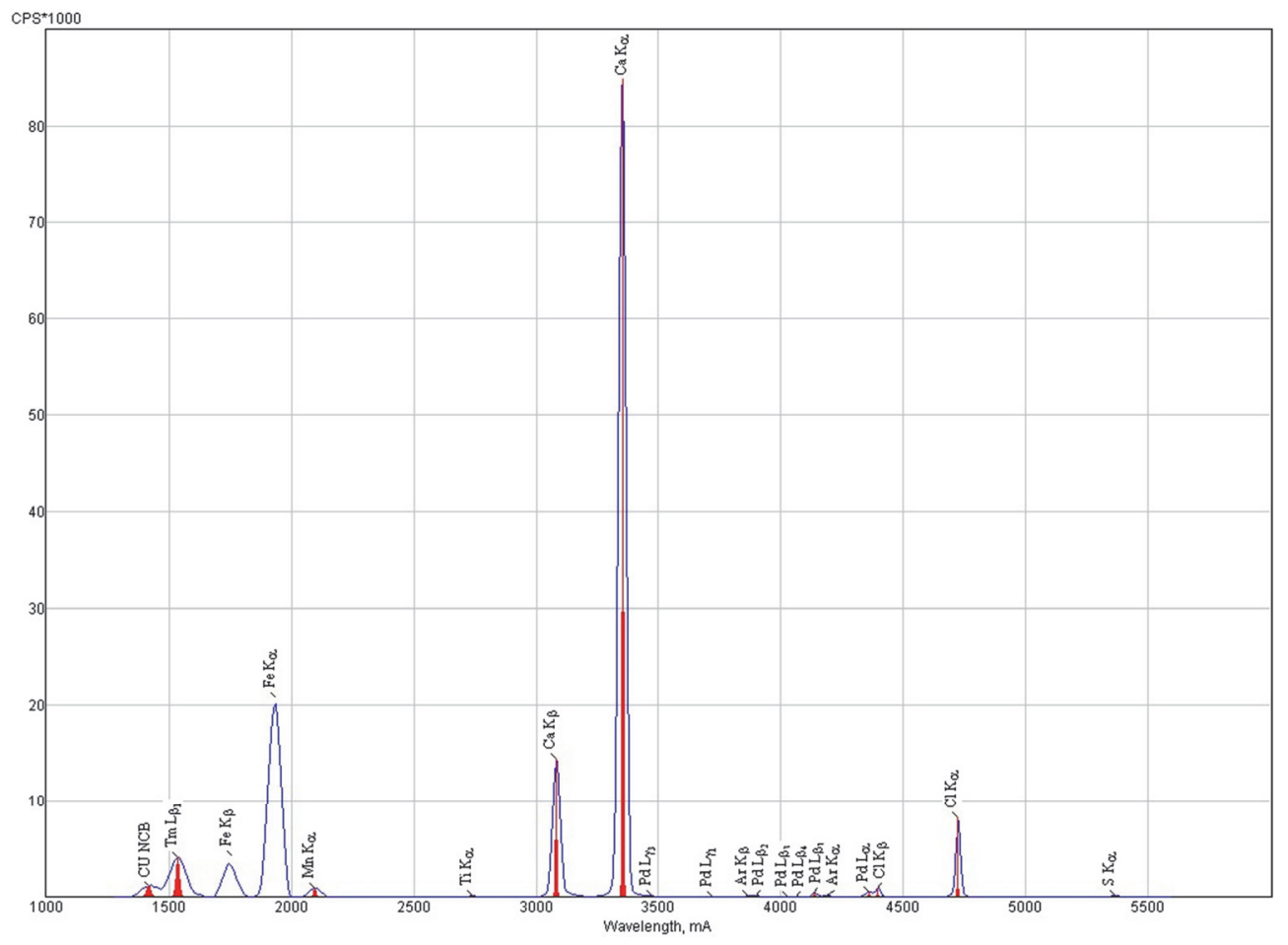

Fig. 6. XRF spectrum of calcareous waste sample A, 0.5-1 m, crystal C (002), $40 \mathrm{kV}, 2.00 \mathrm{~mA}$.

Based on the elemental analysis it was determined that the content of elemental carbon was up to twenty per cent. An attempt was made to specify the type of compounds in which it occurred. The obtained diffraction patterns were compared with the diffraction patterns for pure calcium carbonate available in the X'Pert database. This made it possible to unambiguously identify the presence of $\mathrm{CaCO}_{3}$ in all of the samples. It was also confirmed that the storage of the waste resulted in the secondary carbonisation of the calcium hydroxide used in the production process, according to the following reaction:

$$
\mathrm{Ca}(\mathrm{OH})_{2}+\mathrm{CO}_{2} \rightarrow \mathrm{CaCO}_{3}+\mathrm{H}_{2} \mathrm{O}
$$

Due to the fact that calcium contained in waste occurs in a bonded form, its percentage content in selected chemical compounds was determined. The results are presented in Table 3. The highest value of elemental calcium was bonded in $\mathrm{Ca}(\mathrm{OH})_{2}$, in the range of 21.5$31.8 \%$. Up to $14.5 \%$ of $\mathrm{Ca}(\mathrm{B}, 0.5-1 \mathrm{~m})$ was contained in $\mathrm{Ca}(\mathrm{OH})_{2}$, and up to $7 \%(\mathrm{~B}, 0 \mathrm{~m})$ in $\mathrm{CaCl}_{2}$. A clear tendency of changes in the content of the bonded $\mathrm{Ca}$ depending on the area and the depth of extraction of the calcareous waste was not found. 


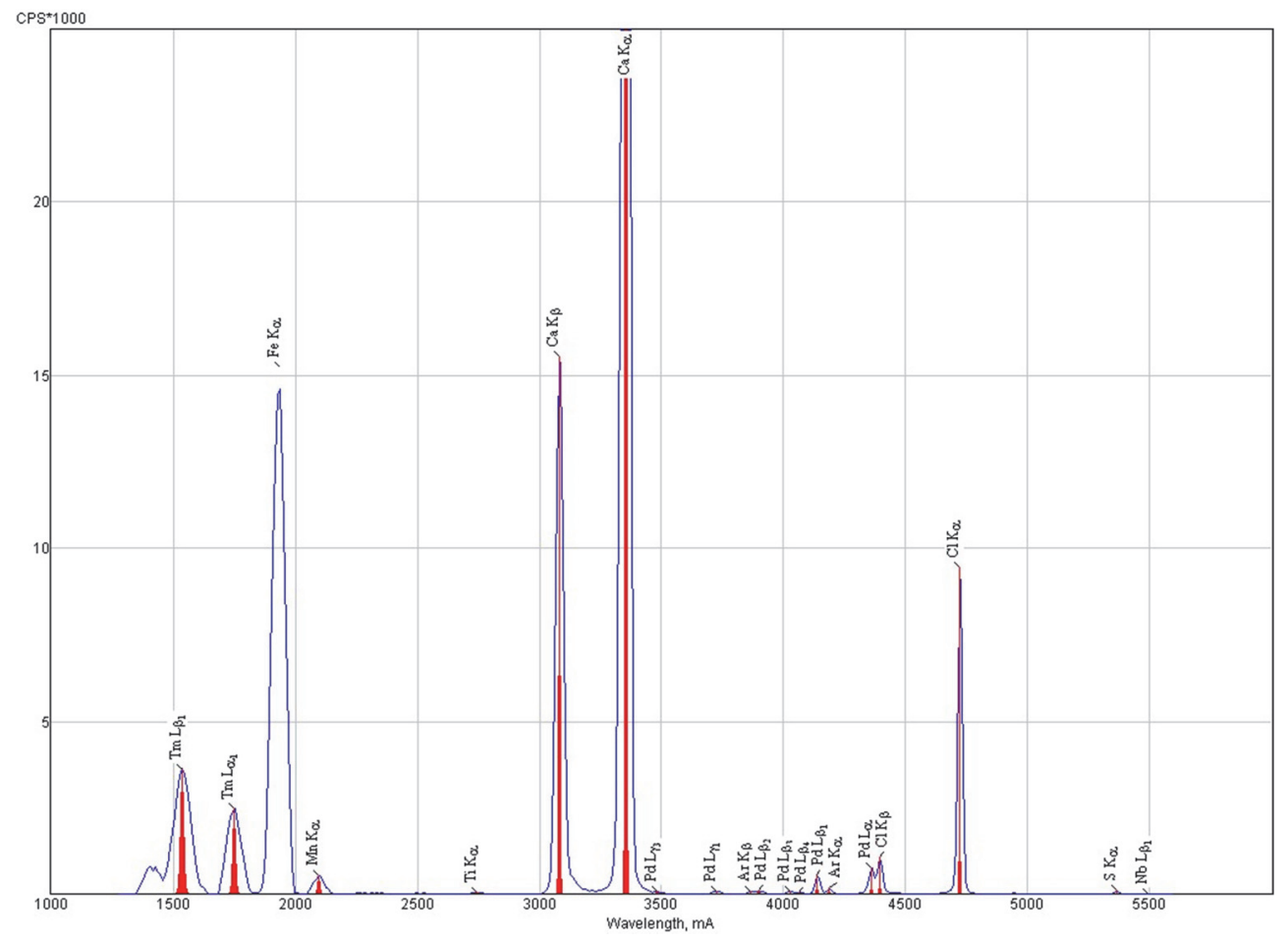

Fig. 7. XRF spectrum of calcareous waste sample B, 0 m, crystal C (002), $40 \mathrm{kV}, 2.00 \mathrm{~mA}$.

TABLE 3

The content of selected calcium compounds in the calcareous waste samples.

\begin{tabular}{lllll}
\hline Area number and extraction depth [m] & A & & B & \\
& 0 & $0.5-1$ & 0 & $0.5-1$ \\
\hline Ca total [\%] & 42.16 & 40.9 & 41.67 & 41.35 \\
Ca contained in $\mathrm{CaCO}_{3}[\%]$ & 24.26 & 31.8 & 25.73 & 21.5 \\
$\mathrm{Ca}$ contained in $\mathrm{Ca}(\mathrm{OH})_{2}[\%]$ & 14.26 & 4.86 & 8.97 & 14.54 \\
$\mathrm{Ca}$ contained in $\mathrm{CaCl}_{2}[\%]$ & 3.64 & 4.24 & 6.97 & 5.31 \\
\hline
\end{tabular}

In order to specify the pore structure parameters of the waste, porosimetric analyses were carried out. The data are presented in Table 4. Sample A $(0.5-1 \mathrm{~m})$ had the highest value of the total pore volume $\left(0.46 \mathrm{~cm}^{3} \mathrm{~g}^{-1}\right)$ and surface area $\left(19.97 \mathrm{~m}^{2} \mathrm{~g}^{-1}\right)$. This sample also had the highest percentage value of porosity (35.2\%). In the other samples (A, $0 \mathrm{~m}$; B, $0 \mathrm{~m} ; \mathrm{B}, 0.5-1 \mathrm{~m})$ the values of those parameters were lower and similar to one another. The surface area was in the range of $11.50-14.07 \mathrm{~m}^{2} \mathrm{~g}^{-1}$ and the percentage porosity was 25 $29.4 \%$. 


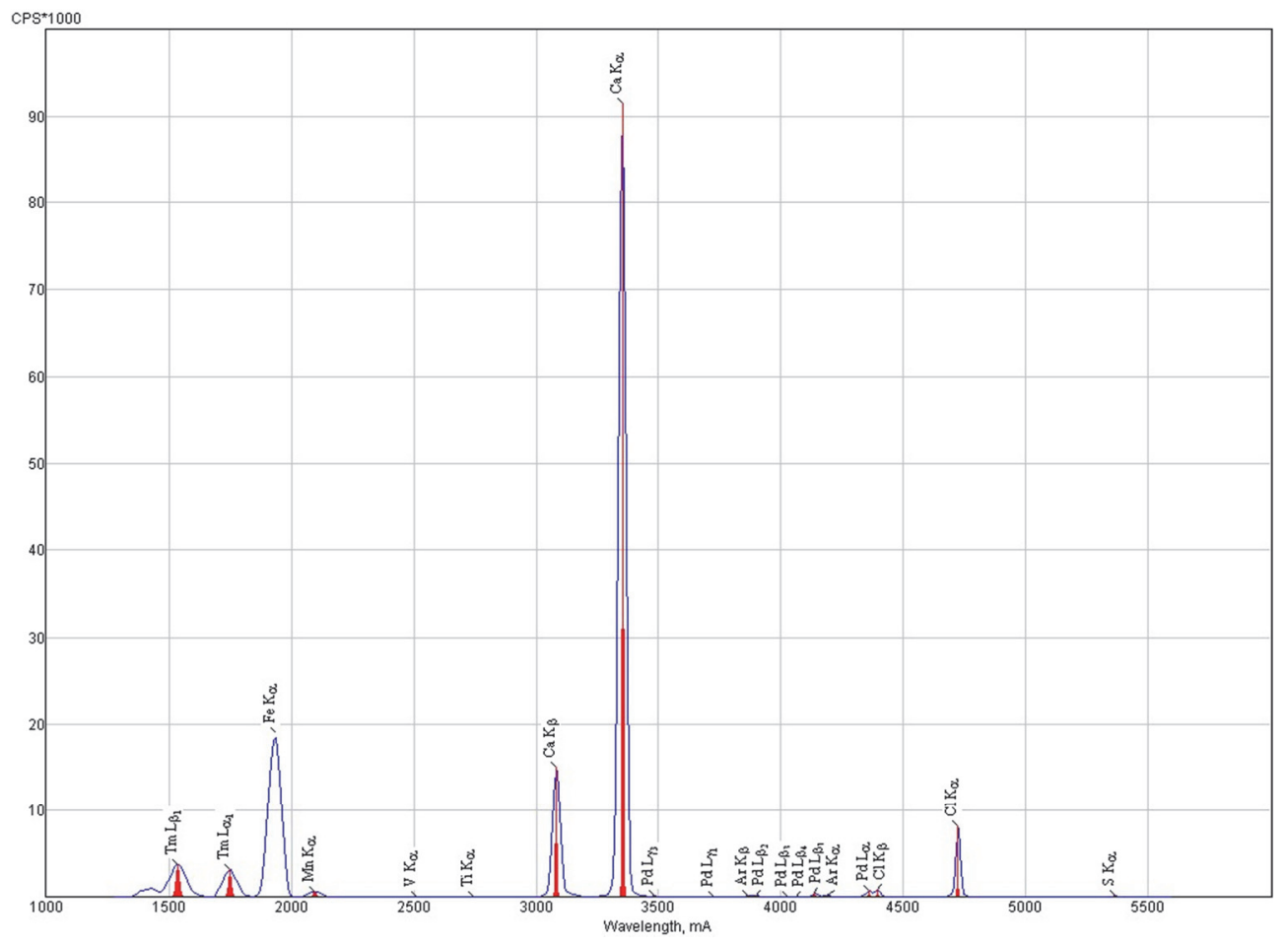

Fig. 8. XRF spectrum of calcareous waste sample B, 0.5-1 m, crystal C (002), 40 kV, $2.00 \mathrm{~mA}$.

TABLE 4

Structural parameters of the samples of calcareous waste.

\begin{tabular}{llllll}
\hline $\begin{array}{l}\text { Area number and } \\
\text { extraction depth }[\mathrm{m}]\end{array}$ & $\begin{array}{l}\text { Total pore } \\
\text { volume }\left[\mathrm{cm}^{3} / \mathrm{g}\right]\end{array}$ & $\begin{array}{l}\text { Surface area } \\
{\left[\mathrm{m}^{2} / \mathrm{g}\right]}\end{array}$ & $\begin{array}{l}\text { Mean pore } \\
\text { diameter }[\mathrm{nm}]\end{array}$ & Porosity [\%] \\
\hline \multirow{2}{*}{ A } & 0 & 0.30 & 11.50 & 106.0 & 29.4 \\
& $0.5-1$ & 0.46 & 19.97 & 70.1 & 35.2 \\
B & 0 & 0.30 & 14.07 & 60.3 & 27.0 \\
& $0.5-1$ & 0.23 & 12.72 & 73.6 & 25.0 \\
\hline
\end{tabular}

\subsection{Determination of the reactivity in relation to $\mathrm{SO}_{2}$}

Ahlstrom's Pyropower Development Laboratory test was used to assess the reactivity of the calcareous waste. The reactivity index $R_{i}$ was determined for all of the samples according to formula 1 , as presented in Table 5. The results are juxtaposed with the reactivity scale shown in Table 1. 
The results of the reactivity tests of the calcareous waste.

\begin{tabular}{lllll}
\hline & A & \multicolumn{3}{l}{ B } \\
\hline $\begin{array}{l}\text { Area number and extraction } \\
\text { depth [m] }\end{array}$ & 0 & $0.5-1$ & 0 & $0.5-1$ \\
$\begin{array}{l}\text { Reactivity index } \mathrm{R}_{\mathrm{i}} \\
\text { Limestone assessment }\end{array}$ & 4.92 & 4.54 & 4.04 & 4.64 \\
\hline
\end{tabular}

The reactivity index values of all of the calcareous waste samples were in the range of 4.0-5.0, which proves that their sorption abilities are sufficient. Clear changes of the index $\mathrm{R}_{\mathrm{i}}$ depending on the area and the depth of extraction were not observed. Such a result proves a weak chemical activity of the waste relative to the acid gas component $\mathrm{SO}_{2}$. For that waste to be used, it is necessary to improve those properties through the use of a properly selected activation method.

\section{Conclusions}

The conducted research presents the full spectrum of physicochemical properties of the selected samples of calcareous waste deposited in landfill sites. The analysed waste was porous and morphologically heterogeneous. The average grain size $d_{3,2}$ (Sauter Mean Diameter) was in the range of 11.0-12.5 $\mu \mathrm{m}$, and the grains occurred in isolation as well as in agglomerates. The surface area of the grains was in the range of $11.5-20.0 \mathrm{~m}^{2} \mathrm{~g}^{-1}$ and the percentage porosity was $25-35 \%$.

The waste was characterised by considerable mass share of calcium, carbon and chlorine. The calcium occurred mainly in a bonded form. The highest percentage amount of elemental calcium (21.5-31.8\%) was bonded in $\mathrm{CaCO}_{3}$, in $\mathrm{Ca}(\mathrm{OH})_{2}$ (up to $14.5 \%$ ) and in $\mathrm{CaCl}_{2}$ (up to 7\%). Apart from the calcium compounds, the chemical composition revealed admixtures of magnesium carbonate, which is also a valuable compound, desired in industrial technologies. As in the case of aluminium and iron, trace amounts of magnesium occur in calcium carbonate, which was the source of the calcium hydroxide used in the technological process. Because in nature, calcium carbonate occurs with various admixtures, trace amounts of alkaline elements as well as Fe, $\mathrm{Si}, \mathrm{Ti}, \mathrm{Mn}, \mathrm{P}, \mathrm{S}, \mathrm{Cr}$ and heavy metals were found in the waste.

In the landfill sites, significant changes take place over time in the phase and chemical composition of the waste. Part of calcium hydroxide undergoes secondary carbonisation and calcium chlorides are washed out into deposits. This results from atmospheric conditions. Hence, among others is the presence of sulphur, which most probably comes from acid rainfall.

The high content of calcium, the problems connected with the storage of this type of waste and the demand for the industrial use of limestone creates the need to study it. The idea of the utilisation of this type of waste included the assessment of the possibilities to use it to remove $\mathrm{SO}_{2}$ from fumes emitted from the combustion of fuels. As the sorption 
analyses in a model gas showed, in spite of the well-developed macro- and mesoporous structure, as well as the high content of calcium and magnesium, the waste samples were not sufficiently reactive in relation to the acid component to be used. According to the Ahlstrom Pyropower reactivity test, commonly used for the calcareous materials, their usability to remove $\mathrm{SO}_{2}$ was 'satisfactory' $\left(4.0<\mathrm{R}_{\mathrm{i}} \leq 5.0\right)$. For such materials to be effectively used, it is necessary to improve their properties. Further search for the possibilities to utilise this type of waste is planned by the authors in the next research stage. This will include the application of a properly selected activation method of calcareous waste, which will improve its sorption properties.

\section{References}

Ahlstrom Pyropywer-Reactivity index. Ahlstrom Pyropower, Technical Paper 1995, accessed on 06.2007, http://www.ahlstrom.com.

http://www.czatkowice.pl/zastosowanie/Strony/energetyka.aspx, accessed on 05.2015.

Hycnar, E., Ratajczak, T., \& Wal, M. (2016). Chalkstone from the Mielnik Deposit as a $\mathrm{SO}_{2}$ sorbent for the energy industry. Zeszyty Naukowe Instytutu Gospodarki Surowcami Mineralnymi i Energia PAN, 95, 157-168.

IUNG, Institute of Soil Science and Plant Cultivation, State Research Institute, Badania odpadów przeznaczonych do rolniczego wykorzystania, accessed on 12.2015, http://www.iung.pulawy.pl/index.php?option= com_content\&view=article\&id=827:badania-odpadow-przeznaczonych-do-rolniczego-wykorzystania-\&catid $=45$ : oferta [in Polish].

Kochel, A., Cieplińska, A., \& Szymanek, A. (2015). Flue gas desulfurisation in oxygen-enriched atmospheres using modified limestone sorbents. Energy \& Fuels, 29(1), 331-336. DOI: 10.1021/ef5021439.

Markiewicz, D., Ochodek, T., Koloničný, J., Rajczyk, R., \& Szymanek, A. (2014). Dry flue gas desulfurization with calcium oxide and limestone in a pilot plant with circulating fluidized bed. Przemyst Chemiczny, 10, 1754-1757. DOI:10.12916/przemchem.2014.1754.

Markiewicz, D., Szymanek, A., Szymanek, P., \& Ochodek, T. (2013). Use of additives to bituminous coal for decreasing the $\mathrm{SO}_{2}$ and $\mathrm{NO}_{\mathrm{x}}$ contents in flue gases from pilot plant with the circulating fluidized bed. Part 2. Addition of limestone and its mixtures with raw sodium bicarbonate. Przemyst Chemiczny, 6, 924-927.

Rawle, A. (2000). Podstawowe pojęcia z dziedziny analizy ziarnistości. Cz.1. LAB Laboratoria, Aparatura, Badania, 5, 22-26.

Szymanek, A. (2000). Badanie modyfikowanych sorbentów wapniowych do odsiarczania spalin. PhD thesis, Wrocław University of Science and Technology, Wrocław.

Szymanek, A. (2008). Odsiarczanie spalin aktywowanymi mechanicznie odpadami wapniowymi. Prace Naukowe Instytutu Inżynierii Ochrony Środowiska Politechniki Wrocławskiej. Monografie, Wrocław, ISSN 0084-2869.

Walawska, B., Szymanek, A., Pajdak, A., Nowak, M., \& Hala, B. (2012). Sorption properties of sodium bicarbonate. Chemik, 66(11), 1169-1176.

Washburn, E.W. (1921). The dynamics of capillary flow. Physical Review 17(3), 273-283. DOI: 10.1103/PhysRev.17.273. 